\title{
A Transcendentalist Nature Religion
}

\author{
Nicholas Aaron Friesner \\ Department of Religious Studies, Brown University, 59 George Street, Providence, RI 02912, USA; \\ nicholas_friesner@brown.edu
}

Received: 28 June 2017; Accepted: 20 July 2017; Published: 26 July 2017

\begin{abstract}
Scholars of religion have often pointed to the Transcendentalists as progenitors of a distinct tradition of nature religion in the United States. Nevertheless, this work has not fully dealt with the problematic qualities of "nature" in light of growing concerns about the ethical and socio-political implications of human powers in the Anthropocene. This paper presents a brief overview of "nature religion" while focusing on the often uneasy way that Ralph Waldo Emerson is treated in this work. By looking at how Emerson is viewed as a stepping stone to Henry David Thoreau, I argue that it is precisely what the tradition of nature religion finds problematic in Emerson-his strains of recurrent idealism - that allows him to have a more expansive notion of nature as the environments in which we live, while preserving the importance of human moral agency. What follows, then, is a more nuanced position in environmental ethics that is informed by an Emersonian sense of the irreducible tension between being created and being a creator.
\end{abstract}

Keywords: transcendentalism; nature religion; Ralph Waldo Emerson; environmental ethics; environmental justice

\section{Introduction}

Among scholars as well as the general American public, it has long been acknowledged that the Transcendentalists have contributed to a specific tradition of environmental religiosity. Their influence has been variously named, both by those who would distance Transcendentalists like Ralph Waldo Emerson and Henry David Thoreau from religious institutions (making theirs a kind of spirituality), and by those who allow that this is a different kind of religious tradition, one less invested in reiterating formal church structures and more in inaugurating a revolution in what religion (here, not opposed to spirituality) will look like in the future. Among scholars of religion, both Emerson and Thoreau have played a major role in the development of what is called a "nature religion" tradition insofar as each articulated a sense of religious reverence for the sacrality of the natural world that is inherited by a long line of readers, many of whom ascribe to them a near-prophetic status. However great its ongoing influence as an analytical category for drawing together a diverse set of religious phenomena under a symbolic engagement with nature, we might wonder whether, as a coherent concept, nature religion stands up to critical scrutiny. For instance, recent scholarship from a range of disciplines has questioned the continuing relevance of the analytic category of "nature" because of its seeming inoculation from an analysis of the effects of social and political power. Taking my cue from these critical reappraisals of the unstated normative undertones of "nature", the question I will explore in what follows is whether a Transcendentalist sense of "nature religion," returning to it so-called problematic Emersonian roots, might be better equipped to deal with questions of twenty-first century environmentalism.

Thus, my goal is to interrogate one aspect of the legacy of the Transcendentalists for religious thought in the United States, focusing solely on the tangled question of a "nature religion". However, I will not interrogate the particular historical trajectory presented by the dominant paradigm of nature religion in this essay-and whether its inclusion of certain voices operates to the exclusion of others-but will instead focus on the unraveling of a certain vision of "nature" that lays at its core. 
In fact, what I will argue in the following is that we can see in miniature what is most troubling about "nature" as an ethical category in the traditional move from Emerson to Thoreau as it is represented by the majority of those who have been interested in the connection between nature religion and environmentalism in the past three decades. My contention will be that swirling within the criticism that is often made of Emerson's proto-environmentalism - i.e., that his idealism prevents him from realizing the true value of nature as something independent of the human, a value that is not merely symbolic and not merely in service of human ethical flourishing-are the tools for an approach to environmental ethics and justice in the present. That is to say, the ambiguity of Emerson's nature idealism allows him to have a sense in which human power and nature power are intertwined, in which nature is more than the wilderness but stands for the environments in which we live. Consequently, Emerson's ideal of intimacy with the world preserves a unique sense of human responsibility while rejecting any picture in which human moral activity is autonomous from the environments it occurs. The lineage of the Transcendentalist interest in nature moves away from Emerson on this point, traveling instead through the tradition of nature writing and a more overt celebration of the land.

My hope is to draw from Emerson the idea that humans now live in a tension with the world in which we are both creators of and created by own environments. This is one of what Stanley Cavell would call the "unhandsome" aspects of our condition, that when we try to clutch the hardest at our world we tend to lose contact with it the most. ${ }^{1}$ By turning back to Emerson, my hope is not to privilege Emerson over any other ethical response-as though he sets out something unique on the American intellectual scene. Indeed, there are many indigenous and ecotheological views that come to a similar kind of claim about human responsiveness to the environment, but which start in very different places. ${ }^{2}$ There are many roads to the place I hope to go. Rather, my hope is to focus on a kind of unconventional Emerson, a figure I believe has been used and misused at the nexus of religion, literature, and environmental thought, all in hopes of offering a view that might have resonance in the twenty-first century.

\section{2. "Nature Religion" and Symbolic "Nature"}

Although it is still in wide usage in an array of fields, the term "nature" has itself come under criticism for a variety of reasons from many different disciplines. For those working in the field of religion and ecology, "nature" is problematic as a term to the extent that it refers to an individual object of religious concern that is often bound to a particular creation theology separating some autonomous order of "nature" from not-nature. This creation theology need not be explicitly monotheistic, for there are a variety of ways to separate the domains of a created order into two distinct (although perhaps entangled) spheres. The problem is that too often this creation theology is considered a neutral or universalizable descriptor. As Roger Gottlieb among others has written, religion and ecology in its early iterations as a discipline dealt explicitly with the question of how humans are to deal with "creation", which was more or less equivalent to the term "nature". Perhaps unsurprisingly, the idea of "creation" in this context uses either an explicit or implicit theological apparatus to preserve the order of nature as a created thing apart from human power. Nature (as creation) was thus viewed as a thing that becomes despoiled by human activity—the human (along with the equally pernicious

1 I follow Tyler Roberts in refining Cavell's reading of this passage by taking it as an argument for receptivity through acknowledgment of the world (Buell 2003, p. 211). As Emerson puts it in "Experience": "I take this evanescence and lubricity of all objects, which lets them slip through our fingers then when we clutch hardest, to be the most unhandsome part of our condition. Nature does not like to be observed, and likes that we should be her fools and playmates" (CW 3:29). In this essay, I will use the standard abbreviations for the works of Emerson: The Journals and Miscellaneous Notebooks of Ralph Waldo Emerson (J) (Emerson 1960-1982); The Early Lectures of Ralph Waldo Emerson (EL) (Emerson 1961-1972); The Collected Works of Ralph Waldo Emerson (CW) (Emerson 1971-2013); and The Complete Sermons of Ralph Waldo Emerson (CS) (Emerson 1989-1992).

2 For instance, much of what I will say seems compatible with what Kyle Whyte and Chris Cuomo have recently described as an indigenous ethics of care with regards to the environment, one in which the human caretaker role arguably has elements of what I term a transcendental intimacy (Whyte and Cuomo 2017). 
"culture") coming to exist in disharmony with creation and therefore pitted against it. Nonetheless, not only is "nature" dubious as a universalizable concept, but without some form of creation theology to delimit the separate spheres of human and nature so that each is autonomous in its own way with powers distinct from the other, the idea of "nature" decoupled from a creation theology begins to break apart. Indeed, this decoupling is exasperated by what now seems empirically undeniable: what were once taken to be the categorically distinct spheres of human and nature are no longer viewed as separate realms with separable spheres of power, but mutually constituting, with no idyllic prelapsarian harmony to which we ought to return. ${ }^{3}$ For many who work in religion and ecology and are worried about how "nature" might provide a false sense of a fully harmonious order, there has been a conceptual change to thinking about the "environment" to avoid the problematic theological overtones of "nature". Instead, as Gottlieb describes, we must focus our ethical gaze on "a nonhuman world whose life and death, current shape and future prospects, are in large measure determined by human beings" (Gottlieb 2006, p. 5).

The conceptual change to talking about environments rather than nature is also meant to acknowledge a fact that now seems undeniable: that we are living in what is now fashionably called the anthropocene, meaning that we are living at a time when human activity and human power have unimaginable impacts on every facet of the Earth. ${ }^{4}$ This is an acknowledgment that in our twenty-first century, globalized industrial society there is no self-sustaining natural world that stands apart from the influence of human power-and vice versa. This is, first of all, an empirical claim to which we are witnesses through climate science, conservation biology, environmental medicine, as well as with the variety of those who work towards environmental justice, among other and diverse fields. But this has a philosophical resonance as well: that is to say, we are not passive receivers of impressions made on us by the world, but active creators of our experiences, beings that are shaped by socio-cultural systems in conjunction with the physical environments that are also shaped by these systems. The social and the environmental are nearly impossible to disentangle — and that is a central element of what the anthropocene forces us to acknowledge. I should note as well that just as Emerson and Thoreau saw humans as animals, my invocation of the anthropocene is not meant to make a categorical distinction between humans and animals (or any other form of life)-although it does take the human species to be exceptional in the sense that, at the present, human activity has a radical world-altering power and the concomitant moral responsibility that entails, even if this responsibility is not equally dispersed among all members. ${ }^{5}$

If we admit the logic of the anthropocene, this presents a problem for how we might talk about "experiences" of "nature", especially those kinds of experiences that form the foundation of "nature religion". In many ways, the realization that there is no autonomous order of nature not deeply shaped, physically and conceptually, by forms of human power has an analog with the debates about religious experience by scholars beginning in the 1980s with Wayne Proudfoot's groundbreaking

3 This also becomes a problem for theological naturalists: insofar as there is nothing that is not nature, then nature ceases to mean anything. For instance, the following question seemed to alter radically Robert Corrington's theological work: "If nature is all that there is, can we even use the word 'nature' in a philosophical perspective in which the concept of the 'non-nature' makes absolutely no sense?" (Corrington 2002, p. 141).

4 My usage of the "anthropocene" here is meant to follow in the work of Jeremy Davies who presents it as "a way of seeing" that "can work as a shock tactic. To say that the earth has changed so much that a whole new geological epoch has begun is a way of driving home the magnitude of recent damage to the living world." Rather than promoting a universalism that absolves individual actors of responsibility, or providing a defense of a technocratic global elite as the saviors of our planet, Davies sees the "anthropocene" as a descriptor of a new epoch in geologic time, one that can encompass as well as celebrate the vast plurality of ecological responses to the effects of human power on the life and health of the planet and its organisms (Davies 2016, pp. 194-95).

5 This is, of course, a contentious portrayal of the anthropocene. For one recent criticism of this view, Donna Haraway argues that conceptions of the anthropocene seem to rely on "human exceptionalism and the utilitarian individualism of classical political economies," which offer up a technocratic and pessimistic solution to environmental problems. She relates this to the "last gasps of the sky gods," the monotheistic religious traditions that see divinity in a human form that transcends the earthly (Haraway 2016, p. 57). 
work. Prior to this period, scholars of religion often treated an individual's religious experience as a kind of preconceptual access to a world that imprinted itself on the subject independent of that person's history, culture, or circumstance. Scholars of religion now see this position as woefully misguided. Instead, we ought to think about religious experiences as one way that people find meaning through a particular combination of their history, cultural frameworks, and the experience of physical things in the world. ${ }^{6}$ Religious experiences always happen in the midst of a complex web of processes that shape them to be what they are. The analogy with nature here should be evident: just as how "nature" once was taken to be an object sui generis that could impress itself upon people apart from their particular contexts, providing a source of normativity for human life that is removed from the social-cultural systems that have (potentially) led us astray, we now understand that there is no such thing out there that is not already mediated — both conceptually and physically —in some way by forms of human power. Consequently, there is no such experience of nature apart from the social frameworks of race, religion, gender, class, nationality, etc., all of which inform how we experience.

It is here where we can also witness the move from what is sometimes called first-wave literary ecocriticism to its second-wave successor (Buell 2005). Whereas early forms of ecocriticism tended towards a celebration of the pristine quality of untouched natural lands and promoted efforts to legally, culturally, and biologically preserve those lands from human interference, second wave ecocriticism tends to take a more circumspect view of nature by beginning with the realization that too much focus on the untouched natural lands of the first wave tended to preclude questions about how "nature" is itself produced. In doing so, this second wave focuses on ways of representing environments that include more than just the wilderness, but also toxic waste dumps, the luxuries of ecotourism, and the variety of urban built spaces (Feldman and Hsu 2007, p. 200). ${ }^{7}$ As ecocritics take this criticism to heart, their work begins to show how "nature cannot be represented as something separate and complete in itself, but rather must be seen in material relation to socially differentiated bodies" (Feldman and Hsu 2007, pp. 205-6).

Nevertheless, this thorough critique of "nature", as a category treated apart from the social and historical forces that shore up its coherence, seems not yet to have been fully brought to bear on work exploring nature religion. Indeed, when Albanese (1990, p. 6) coined the term to refer to that somewhat diffuse collection of forms of religiosity that have a common way of "organizing reality" around a concern for the sacrality of nature, she was more interested in whether this proposed category could hold together as a descriptor of a "religious" phenomenon, as opposed to something quasi-or irreligious. Much of the conversation has followed this lead, asking whether it holds up as an accurate definition of "religion" without either dissolving all quasi-religious phenomena into religion proper or dismissing all phenomena that do not toe a rather narrow theological conception of what can count as religion (Berry 2011). That is to say, of the two constitutive conceptual components of "nature religion", it has been the "religion" component that has garnered the bulk of scholars' attention because it seeks to include a diverse array of religious phenomena under a single umbrella. In Albanese's follow-up work, it is just this problem that draws her attention: she worries that "the appearance of nature religion dissolved almost as soon as it could be identified," not because there are questions about the boundaries of the category "nature" and the various and diverse meanings it might have, but because she has trouble answering the question of "where does religion stop and something else begin?" (Albanese 2002, p. 23). "Nature" isn't a problem for Albanese because she treats it as the "reality" in which human experience occurs, a stable point made up of the "forces and factors that delimit the human project-aspects of life over which humans, literally, have no control and before which they must bow" (Albanese 2002, p. 24). There isn't a discussion of how this reality of "nature" shifts and

6 The classic presentation of this view was given by Proudfoot (1987). For more recent work that extends this view, (see Bush 2014; Taves 2009).

7 In this way, ecocritics are turning to the same environmental phenomena that sociologists pursuing environmental justice, such as David Pellow, have been exploring in recent years (Pellow 2002; Park and Pellow 2011). 
morphs depending on how it is conceived, or whether the idea that there are forces outside of human control ceases to be an adequate way of describing nature in the anthropocene where we only have quasi-natural phenomena. As I will show below, Albanese, as well as much of the other nature religion literature, has trouble putting Emerson under the "nature religion" umbrella precisely to the extent to which he seems unsure of "nature" as a fixed reality in which human life participates.

The discourse around "nature religion" has generally followed this path laid out by Albanese. For instance, Taylor and Horn (2006, p. 166) define "nature religion(s)" as "umbrella terms for religious perceptions and practices that, despite substantial diversity, are characterized by a reverence for nature and consider nature to be sacred in some way," with an added sense that it involves "the feeling some people have of being bound, connected, or belonging to nature." Taylor and Van Horn see this as a move away from efforts to achieve a transcendence of nature. For them, anti-transcendence opens the door to a different kind of nonsupernatualist religion that will inspire environmental action and a "reverence for life" (Taylor and Horn 2006, pp. 179-80). Similarly, Dacy (Dacy 2005, p. 1175) in The Encyclopedia of Religion and Nature describes "nature religion" as "a type of religion in which nature is the milieu of the sacred, and within which the idea of transcendence of nature is unimportant or irrelevant to religious practice." There is a general tendency toward ecocentrism in these works, which explains the aversion to certain notions of "transcendence". What is to be transcended is human culture and the problems therein, but not the natural world as the context in which all human thought and activity occurs. Indeed, it is the full-bodied "reality" or "nature" that ensures that "nature religion" can operate as a set of dispersed religious phenomena that all roughly employ a similar sense of the sacrality of a shared referent. Indeed, there isn't much interrogation of what kind of creation theology would hold this "nature" together, or whether that theology is as shared as it is sometimes made out to be. In this regard, scholarship on nature religion is similar to first-wave ecocriticism.

One of the places this commonality comes out most strongly is the tendency to treat Emerson as a stepping stone to Thoreau. When looking at the standard histories of US environmentalism that informs work on nature religion, there is no doubt that Thoreau is the more important figure, the one who inspires the earliest generations of explicitly environmentalist writers and who is credited as being perhaps the first American naturalist. In Thoreau's work the land speaks to him in often finely attentive ways, ways to which he is more attuned and better at celebrating than the ephemeral-sounding Emerson..$^{8}$ Indeed, Thoreau's volumes of natural description and extended natural metaphor are so aesthetically superior to Emerson's occasional observations that no one would dare put them on the same level. In Buell's formative volume for understanding the American environmental imagination, he makes Thoreau's treatment of the personified nonhuman world the central thread of the work, enacting a tradition of poetic animism that provides the bond between ecology and ethics. As Buell (1995, pp. 208-9) rightly describes the dominant paradigm of environmentalism in the US, Thoreau is seen as having a "personal intimacy with nature," in which an animated Walden functions as "a living presence, not merely a 'neighbor' but a mentor, a role model." ${ }^{\prime 9}$ When Buell offered his updated understanding of ecocriticism in 2005, Thoreau's importance diminishes as a more global and justice-oriented literature rises to prominence, even though Buell

8 There is still a question (as there is for Emerson as well) of whether the later detailed naturalistic observations of Thoreau witness a religious disenchantment when compared to his earlier, more spiritually enthusiastic writing. As Hodder (2011, p. 473) puts it: "According to this decline narrative, as we might call it, at this watershed moment in his life [his late thirties into his forties]. Thoreau began to abandon his earlier spiritual euphoria, along with his former religious idealism, and devoted himself instead to a narrower set of scientific commitments." Needless to say, oftentimes the literature that is more concerned with Thoreau's naturalism as the archetypal environmentalist expression tends to view this as a positive change, rather than an extension of an coherent religious project from the beginning. In general, there is a tendency to "secularize" the prominent Transcendentalists when considering their contribution to the creation of a distinctive literary tradition. For an exploration of this, (see Van Anglen 1998).

9 Buell defends Thoreau's blatant use of the pathetic fallacy as a means by which to present environmental care with a voice, a way of conceptualizing the environment as sacred on social terms. That is to say, because Thoreau was able to recognize an intimacy with nature through conceptualizing its presence to him in terms of human social relations, he was able to respond to it as though responding to a person-as, in a sense, allowing the things of the environment to speak to him in 
hints at ways of bringing Thoreau into this conversation by expanding his concern beyond the strictly naturalistic literature inspired by him. ${ }^{10}$

Accounts that are more sympathetic to Emerson, such as Gatta (2004), still tend to find the fulfillment of the environmentalist turn in the ecocentric animism of Thoreau. Pitting Thoreau's "hearty empiricism" against Emerson's "metaphysical abstractions," Gatta finds the latter to dwell too much on the idea that humans are creators of the visible world, and that the environment is too often nothing more than the mind's projection (Gatta 2004, p. 89). Gatta reads Emerson as failing to attend properly to how his understanding of "nature" was historically mediated in those moments when he sensed that he had somehow gotten to the truth of nature by means of a heightened individual experience (Gatta 2004, p. 95). Thus, Thoreau is the one who finds a way of accounting for how human imaginative abilities "half-create" our interaction with a place, avoiding a simple celebration of the pristine and untouched wilderness by portraying the human-environment relationship as one of co-creation (Gatta 2004, p. 131). As Thoreau interprets nature through his carefully crafted empirical observations, he comes to self-consciousness about himself as interpreter. Thus, Gatta finds in Thoreau a less problematic theology of creation that makes the idea of living deliberately in close relation to the natural world an intentional act of acknowledged co-creation.

In general, the literature on nature religion reinforces the picture given by the ecocritics, where Thoreau supersedes Emerson by taking significant steps to overcome his anthropic idealism with an ecocentrism that is informed by his scientific naturalism. Albanese's work is emblematic in this regard, as she attributes to Emerson a confusion between "a view of matter as 'really real" and "a view of matter as illusion and unreality" — forcing a dilemma between choosing to view "nature as the embodiment of God" and thus the home for human life, or "transcending" nature "for higher things" (Albanese 1990, p. 82). She even argues that Emerson was aware of this shift from "Nature Major to Nature Minor" and felt the need to apologize for it once he realized that he was stuck in a problem that he was unable to remove himself from (Albanese 1990, pp. 85-87; 2002, p. 67). Thoreau, at least in Albanese's earlier work, corrects some of what she sees as Emerson's problem concerning the inherent "reality" of nature, replacing it with a more thoroughly "unchastened embrace of matter" (Albanese 1990, p. 87). Taylor and Horn (2006, pp. 169-70) reiterate this move, claiming that Thoreau and his inheritor John Muir were "far more interested in nature for its own sake than Emerson," thus making them "naturalists who were more scientifically inclined than Emerson," portraying their mentor Emerson as more representative of the strain of Transcendentalism that leads to contemporary New Age spiritualities than a deep environmental concern. ${ }^{11}$

The problem with all these moves from the symbolic "nature" of Emerson to the scientific naturalism of Thoreau is that the juxtaposition between Thoreau and Emerson—-the empirical observer versus the metaphysical spiritualist—privileges an empirical model as the primary means by which to understand the environment, which is understood as a nature that exists waiting to be uncovered. ${ }^{12}$

his own language. He is able to treat Walden as a mentor precisely because he has augmented himself in order to stand in a relationship of intimacy with it. It is through nature's personhood that Thoreau brings ecology and ethics together.

10 "But to think of the Walden persona, through an environmental justice lens, as struggling with the concerns of poverty, downward mobility, and chagrin at being socially reduced to the equivalent of an ethnic other helps both to define the book's mental limits-the presumption of the still-comparatively privileged, subsidized Yankee likening his predicament to that of a wandering Native American basket-peddler-and to mark off what makes Walden a more searching ecocultural inquiry than much of the latter-day voluntary simplicity literature partly inspired by it" (Buell 2005, pp. 122-23).

11 Additionally, the three entries in the Encyclopedia of Religion and Nature that deal with Emerson, Thoreau, and the Transcendentalist movement, by Gould (2005), argue that Emerson cared more about nature's symbolic power than its scientific importance, that Thoreau goes "beyond" Emerson with his scientific naturalism, but also Thoreau goes beyond most of the Transcendentalist movement in general, which she reads as interested in the moral and aesthetic value that "lay 'behind' or 'inside' external, natural phenomena," showing their interest to lie more in a symbolic nature than an actually physically existing nature.

12 One could argue that Thoreau's work pushes back on some of this simply juxtaposition. For instance, his claim in "Walking" that he lives a "border life" should cause us to question the very boundaries that seem necessary for a concept like the "natural". 
We are given the impression that if one is to be environmentally conscious, then he must become a naturalist. Often it seems that the conflation between environmentalism and naturalism is meant to express the rejection of any attempt at human transcendence-whether with a notion of divinity or not-because it would seem to distance one from a concern with nature. While "nature" is acknowledged to be a human construct for this model, it still treats it as though it is a reality somewhere out there awaiting exploration - and, we might add, conquered by a kind of masculinist knowledge of it. Consequently, a picture of nature as pristine wilderness seems to be lurking always in the background for this empiricism, always supplying that which is to be constructed by human cognition. What we lose, then, are the ways that nature is physically constructed by humans, not just conceptually. And the pristine wilderness seems again to run afoul of critiques of creation theology. What such a theology of creation fails to give us is a way of understanding that, for instance, our social and political systems have been inflected by racist ideologies and have formed the environment into a physical instantiation and instrument for the perpetuation of racism. Racialized human systems produced racialized environments. A theology of creation that doesn't take this into account fails to allow us to attend to the ways that the formation of the environment comes to represent a type of slow violence, to use Rob Nixon's term, one in which human actions cause changes in the environment which, in disproportionate ways, map onto socially marginalized peoples and cause them violence in long temporal durations (Nixon 2011, p. 2). That is to say, the physical landscape itself becomes the carrier for social injustice, remaking and remapping the environment according to social and political power-and there is no way of escaping this power. ${ }^{13}$

Let me consider one more preliminary concern before turning to my presentation of Emerson. To recuperate a sense of an Emersonian nature religion that gives us tools for thinking about the ambiguity of the human-environment relationship, we will need a way of understanding how nature religion can find forms of authority that are more than individual projection, that finds authority in the reality of nature even when "nature" is understood as a (partial) product of human power. Take, for instance, a criticism of Emerson made by Lundin (2005) that expresses a discontent with the modernity and the perceived liberalism of an Emersonian religion. In From Nature to Experience, Lundin tracks the loss of a kind of authority offered by the natural world as the locus of God's revelation, which is replaced by a particularly American sense of the authority of individual experience. For Lundin, this is a story of the decline of religion (or, more appropriately, a certain understanding of Christian orthodoxy) in the face of secularizing pressures, a decline which can be seen in miniature in Emerson's corpus. ${ }^{14}$ By turning the locus of authority from nature to experience, Lundin argues, the human becomes the measure of all things, and therefore the measure of nothing. Lundin has a reluctant sympathy for Emerson, who he reads as trying to preserve a thread of moral reality for nature through his doctrine of correspondence, as though Emerson saw the writing on the wall but was helpless to do anything about it. Many readers of Emerson (Lundin singles out Richard Poirier, but we might include Cavellians and Pragmatists of all stripes here as well) have de-divinized Emerson by removing that last thread of moral reality from him, emptying him of all his "metaphysical dimensions" (Lundin 2005, pp. 63, 65). From Lundin's rhetoric, it is clear that this is a story of cultural

13 As Nixon (2011) notes, to respond to the contemporary situation of slow violence, more than a careful empirical attention to the environment is needed. In fact, the notion of wilderness that too often gets substituted for the environment in some ecocriticism as well as work on nature religion generally serves to obscure these formations of social and political power. Instead, we need creative representations that make visible what often goes invisible-i.e., the forms of environmental change that have disproportionate impacts on the socially marginalized because they occur in non-spectacular ways in ordinary everyday spaces. As Gottlieb (2006) pointed out above, there is no longer a sense of a nature that is not a product of or subject to human power-what we have no not are various and different environments, inflected in various ways by forms of human power and activity, and we need not look too far to find them, but we must make efforts to look.

14 In the short eight-year period from Nature to "Experience," Lundin sees the crucial moment where American intellectual culture moves away from the authority of (Christian) tradition. This loss of traditional authority represented by the turn to experience would eventually take hold among the American pragmatists, culminating in the evacuation of all forms of non-experiential authority for the ungrounded, endless theorization that he claims to find in Richard Rorty (Lundin 2005, pp. 2-3, 8-9). 
decline. ${ }^{15}$ As Lundin presents it, the loss of authority other than the self is a theological problem, and it is only made worse by an Emersonian theology which, as he conceives it, gives authority to individual experience against the authority of tradition, an authority that cannot be dethroned by anything other than the active self in its self-making activity. And if the active self is the only locus of authority, then there will be little regard for any ethical obligation imposed on the self from outside it-in this case, by one's environment.

In many ways this is one of the longstanding criticisms of Emersonian religion. A version of it is found in Orestes Brownson, the Transcendentalist turned Roman Catholic who departed with Emerson over the latter's commitment to promoting the moral sentiment as an insight into one's own soul, rather than seeing that morality required "obeying the command of a power out of him, above him, and independent of him" (Brownson 1991, p. 194). According to this criticism, the Emersonian active self that needs only to obey itself loses the sense of obligation entirely—or, as Brownson put it, morality becomes just "transcendental selfishness" and "pure egotism" (Brownson 1991, p. 196). Oftentimes this became, in Emerson's day, the claim that Emerson dismissed traditional Christian practice when it seemed personally disagreeable to him, making it so that individual distaste becomes the primary determinate of one's morality. ${ }^{16}$ One could offer a similar criticism of Cavell's work and those inspired by him to the extent that it promotes an Emersonian self that is interested only in its untethered linguistic becoming (Buell 2003; Friedman 2009). Without some strong claimant outside the self that can serve as a source of authority that dampens the individual self, the criticism goes, the self swings too freely, and in the Cavellian case, revels too intently in its own playful creative power. Unfortunately, those who would make this criticism of Emersonian religion often hold a static conception of "authority" - that of a particular theological orthodoxy, either an orthodoxy of the book, church, or spirit. Without that, the criticism would go, there is nothing but the willing of the individual self.

With that in mind, we must attempt to swim among these two pressures, neither succumbing to the tendency to defer human power to the power of nature, nor allowing the individual self to assume complete world-making power. Indeed, I will try to show that it is precisely in this tension that Emerson's work can be informative. Furthermore, if we are to engage in a recuperative project of turning to Emerson for a nature religion that is fit for a twenty-first century understanding of the often tangled and mutually constitutive humans-environments relation, then we will need to be doubly insecure about our conceptual pairing of "nature" and "religion". Neither stands as a constant grounded by the other: "nature" is the not the universal reality or shared context that collects a diverse set of religious phenomena, and "religion" is not a theologically constant phenomenon that collects diverse notions of nature into a single discourse. Because the scholarly literature had dealt with the latter concern for what is religious about "nature religion, in the next section I focus on just the former of these concerns by giving an account of Emerson as suppling an ideal of intimacy with the world that preserves the sense of human responsibility (not collapsing human agency in the ecocentric moves that have been characteristic of movements in deep ecology), while eschewing complete human autonomy from physical environments (the claim of anthropomorphic approaches to the environment). Through a cauldron of self, community, and environment, various competing senses of authority emerge. This, I claim, is a product of Emerson's idealism when understood properly. That is, his idealism is not concerned with the mastery of creation through "manipular" means, nor is it about metaphysical abstraction (or, alternatively, transcendence) to the point of disregard for the

15 The last line of his book reinstitutes the kind of authority that he feels has been lost in the liberal turn to experience: "In that silence [of the cross], we may hear a word of abiding comfort, and in this insulted face, we may see an authority that we can indeed call master" (Lundin 2005, p. 202).

16 This claim continues today. For instance, in Barbara Packer's analysis of the Lord's Supper Sermon, Emerson rejects the rite because of the "boredom" that he felt towards it "elevat[ing] distaste into a principle of criticism," which she reads as an instance of religious "indifference" (Packer 2007, p. 9). 
physical-rather, it is about a careful acknowledgment of the power of human creativity and the need for that creativity to be wielded appropriately in relation to the very real bonds of the self that normatively bind it.

\section{Emersonian "Nature" "Religion"}

It would be wrong to suppose that Emerson had a single conception of "nature" throughout his career. Indeed, there is a way that he is building his idealist conception of nature throughout his corpus. Accordingly, to make my case that Emersonian "nature" can be helpful for a different kind of nature religion, I will focus on four essays from different periods of his life: Nature (1836), "The Method of Nature" (1841), "Nature" (1844), and "Illusions" (1860). These essays are by no means exhaustive, but when read together, they present some of the fundamental aspects of how Emerson approached nature, as well as many of the elements that scholars have found to be anathema for an environmental concern. My goal, in particular, will be to develop an Emersonian notion of ecstasy in relation to religious piety, and to show how this relates both to the environment and the function of human agency.

Although his first book, Nature, stands as perhaps his most well-read exposition of a transcendentalist view of "nature," it is not without its ambiguities-something that the literature on nature religion has been right to identify. From the beginning of the book we are told that there are two senses of nature: first, the "philosophical" sense that separates Nature (or the "not-me") from Soul (the human subject); and, second, the "common sense" of nature, which treats it as "essences unchanged by man," separate from Art, which is the mixture of human will and nature (CW 1:8). ${ }^{17}$ The glibness of the way these positions are presented, in conjunction with the assertion that the differences between the philosophical and the common senses of nature will cause "no confusion" for his inquiry, already seems to indicate that something sly is happening. It is as if we are led from the outset to be suspicious of this distinction between soul/human and nature, primed to see perhaps how this Cartesian inheritance doesn't hold up to critical scrutiny. Indeed, the arc of the first main section of the extended essay, appropriated labeled "Nature", culminates with a subtle rejoinder to those who would treat nature and the human as distinct. We might begin our inquiries with the sense that nature is "the integrity of impression made by manifold natural objects" which the poet has the eyes to see as though an independent witness to a manifold imparting ideas or sentiments according to its own integrity, but we end the chapter with the realization that our "delight" in nature is self-produced, that "Nature always wears the colors of the spirit;" that is, our spirit (no longer just the poet's), which can be joyful one day and "overspread with melancholy" the next, plays a determining part in dictating how these supposed "essences unchanged by man" are seen (CW 1:9-10). Even the so-called transparent eyeball passage is said to occur "in good health," prompting us to wonder what such an experience might look like to one in "poor" health (CW 1:9).

This, of course, draws attention to the infamous "crack" that generations of scholarship have pointed to as Emerson's admission that his attempt to weld together the realism of the first five chapters with the idealism of the last two chapters-using his transitional "Idealism" chapter-ends up being a failure. The "Idealism" chapter seems at best to waver in what it aims to do. It gives us the five ways that one might understand idealism ("motion, poetry, physical and intellectual science, and religion") but ultimately doesn't seem to favor one over the others. Instead, Emerson discloses that he has "no hostility to nature, but a child's love to it" and that "all right education" ought to go towards promoting the realization of "man's connexion with nature" (CW 1:35-36). In fact, the chapter both begins and ends with the importance of the "active" over the "reflective" as a means to respond

17 Emerson's distinction between me and not-me calls to mind Fichte's distinction between Ich and Nicht-Ich, which Emerson would most likely have received at second-hand through a combination of Thomas Carlyle, Samuel Taylor Coleridge, Victor Cousin, and Frederick Henry Hedge (Greenham 2012, pp. 70-81). 
to the "noble doubt" that idealism raises about the existence of the world apart from the human, culminating with the claim that philosophy and virtue cannot simply take the position of watchers in an ideal world, but must marry this "watching" to "doing" (CW 1:30, 36) ${ }^{18}$ Importantly, it is love that Emerson returns to at the end of the book, excoriating a materialist science and philosophy that seeks only to fill up notebooks with facts about nature, urging the naturalist to attend also to himself and his position in which "the axis of vision is not coincident with the axis of things" (CW 1:43). In the end, then, the naturalist needs not only to "perceive" nature, but must love it as well, love it in such a way that his "thought is devout, and devotion is thought."

Admonishing the cold naturalist not to forget the importance of his love does not strictly solve the idealist-realist division, because it doesn't tell us the true nature of our subjective influence on an objective world. Nevertheless, this affective dimension of one's love for nature-one of Emerson's inheritances from the Romantic tradition and his Aunt Mary Moody-reverberates throughout the corpus. In the essay "Love" from Essays: First Series, Emerson writes that he is pained by the accusation that his lectures have been too intellectual, and thus "unjustly cold to the personal relations" (CW 2:101). In response, he links together three ideas: the sense that "persons are love's world," the power of nature to evoke this love, and the impact of love on the "social instincts." For Emerson, this is a linkage that occurs in youth and reverberates throughout the life of the individual even as she might no longer be able to "see" nature in that youthful way (CW 2:102). What is striking about this essay is Emerson's usage of a kind of animism to describe how nature can be an object of love that becomes ethically significant. Through this love, "Nature grows conscious." 19 Emerson even evokes the idea of the flower, among other things in nature, as a kind of intelligent being. ${ }^{20}$ What the essay is concerned with is the "training" for a love that looks for virtue and wisdom everywhere, and uses an affection for the natural world as a place in which to cultivate this virtue and wisdom (CW 2:109). Emerson is clear that there is a current of idealism operating below the surface here: it is not that when one looks on nature with the right eye one sees it as it truly is, but that when one looks on nature with a particular kind of eye for it, then it will become the kind of animated intelligent thing to which we ethically respond. Emerson accepts the Kantian point that we do not see nature as it really is, but he rejects the idea that this empties nature of its ethical power in shaping us. The sin, as Wendell Berry (2000, pp. 7-8) points out, is not that our ideas imprison us, but that we presume "to reduce life to the scope of our understanding," which "is inevitably to enslave it, make property of it, and put it up for sale." When we do this, we reduce the "moral complexity" of the world.

So far so good, one might say, but that doesn't do much to answer our worries about the crack between realism and idealism. His 1841 lecture, "The Method of Nature," goes a long way towards refining his position on just this point. In this lecture, Emerson develops the importance of a position of ecstasy, which he connects with a kind of religious piety and receptivity that stresses both love over knowledge and an "intimate divinity" (CW 1:136). Like many from the period, the lecture intends to argue against a materialist and empirical reduction of nature to merely a tool for human

18 Greenham (2014, pp. 89-90) sees Nature as an attempt to bring together idealism with the active shaping of a "nature" which is not separate from the human: "Nature, at the last, for Emerson, is not something material that exists in opposition to us, in excess of us; nature is that which we are inside and out. This is what Transcendentalism means. It is the discovery of ourselves through the process of giving shape to the natural world."

19 This is also a common sentiment in the journals. For instance, in a passage related to Nature: "I love the wood god. I love the mighty PAN. Yesterday I walked in the storm. And truly in the fields I am not alone or unacknowledged. They nod to me \& I to them" (J 5:179).

20 "Every bird on the boughs of the tree sings now to [the youth's] heart and soul. The notes are almost articulate. The clouds have faces, as he looks on them. The trees of the forest, the waving grass and the peeping flowers have grown intelligent; and he almost fears to trust them with the secret which they seem to invite. Yet nature soothes and sympathizes. In the green solitude he finds a dearer home than with men." (CW 2:103). The personification of the flower as having important value for ethical formation is a common thread in Romanticism. Wordsworth $(2002$, p. 85) writes about the daffodils in The Grasmere Journal: "I never saw daffodils so beautiful they grew among the mossy stones about \& about them, some rested their heads upon these stones as on a pillow for weariness \& the rest tossed \& reeled \& danced \& seemed as if they verily laughed with the wind that blew upon them over the Lake." 
advancement, a collection of facts cataloged in scientific journals to promote better consumptive practices. Emerson includes the metaphysical philosophers among those who engage in this reduction, since they attempt to analyze and observe nature to come to some ultimate indubitable cause of all things. These intellectual projects are bound to fail because they approach nature in the wrong mood, trying to wield intellectual power over it, as a thing fit for their ways of seeing. To them, Emerson proclaims: "Known [nature] will not be, but gladly beloved and enjoyed" (CW 1:125). ${ }^{21}$ Trying to "know" nature is related to the grander pretense of humans to suppose that their welfare is the final end that the natural world pursues at all cost: i.e., "to make holy or wise or beautiful men." To counter, Emerson argues that nature has a "universe of ends," not all of which aim to the benefit of humans, and as such, its work must be represented as one of "ecstasy" - "that redundancy or excess of life" that is "the genius or method of nature" (CW 1:125, 127). Emerson puts this view into the voice of nature as it speaks to presumptuous human creatures who wish to see themselves as the focus of the world's development: "my aim is the health of the whole tree,-root, stem, leaf, flower, and seed,- -and by no means the pampering of a monstrous pericarp at the expense of all the other functions" (CW 1:126). The pericarp metaphor serves a dual purpose: as the part of the tree that is most often eaten by humans, we would suppose that if the tree were created for human benefit, the pericarp would certainly be comparatively monstrous, drawing resources at the expense of the rest of the tree; however, the pericarp is also the human, that one fruit on a larger tree that feeds it, but not at the expense of everything else. So while we are not "strangers or inferiors" to nature, and "it is flesh of our flesh, and bone of our bone," this does not mean that our being a part of nature ought to bring us comfort (CW 1:123). For to know that the progress of nature aims to the benefit of better humans is to subscribe to a creation teleology that Emerson would say represents human hubris. Emerson believes that certain scientific advances, in fields such as astronomy especially, ought to enlarge how we understand theology so as decenter the human in our understanding of the universe, helping us to move away from those doctrines-he singles out the "theological scheme of Redemption" - that would put the human at the center of the universe's concern (CS 4:156-57).

In keeping with the emphasis on doing, ecstasy is not meant to breed inaction-precisely the opposite. Indeed, one must move from the universals of nature conceived in the reason to particular actions in the world. For the human to have the "ecstatical state" take place within-a kind of mirror of the world without-then one should become the "channel through which heaven flows to earth," acting in accordance with the demands put upon one by the work that must be done (CW 1:130). This is why one must be "receptive" - a religious posture which Emerson equates to both "piety" and "veneration" (CW 1:130). The implication is not that one needs to have a kind of mystical withdraw in which one receives communication from nature that instructs him on what to do. Quite the contrary. Reception or piety means that one must be an active ethical agent in the world who is seeking always a better and better realization of the needs that must be fulfilled in the present. Importantly, though, one must do this in a particular way: "This ecstatical state seems to direct a regard to the whole and not to the parts; to the cause and not to the ends; to the tendency, and not to the act" (CW 1:131). What Emerson means here is that one cannot simply perform a set of acts and think that he has gotten it right. These acts must be performed with an eye towards the "spiritual" or the "supernatural" —otherwise the acts are just "a cup of enchantments" that seeks after self-satisfaction or the achievement of human ends. Our gods must always be "approached, never touched," because our acts aspire towards a grander world than we could imagine, where we are overpowered by an enthusiastic love for the world, not a love of a set of some things in it (CW 1:133). This love is opposed to mastery and control, it "looks up and not down; aspires and not despairs" (CW 1:134).

It is in this way that Emerson, probably to the chagrin of liberal Unitarians in his own day, can praise the dignity of a fading Puritanism, where "privation, self-denial, and sorrow" were valued

21 There are resonances here with Cavell (2002, pp. 242-43) reading of skepticism. 
above all else, and where "A man was born not for prosperity, but to suffer for the benefit of others, like the noble rock-maple which all around our villages bleeds for the service of man" (CW 1:135). Nature's lesson, according to Emerson, is "intimate divinity," one which keeps the best parts of Puritan piety and its sense of humble service, but which gets rid of the divorce between "intellect and holiness" and stresses the importance of performance in the world, or taking learning and "reducing" it to practice. With an intimate divinity, among its many meanings, we get the sense of how humans are to shoulder the responsibility of responding to the claims that the world issues to us, without neglecting the special world-making power that the human has. Intimacy is here not an intellectual relationship only, but a relationship of affection, or being drawn up by one's love to promoting a better world than the present. This world won't be saved by technology, since the pursuit of mastery through technology, both material and intellectual, leads people to suppose falsely that nature ineluctably aims towards human gain. Nature is in what he calls "perpetual inchoation," constantly rebuking the human who considers her aspirations to be the final ends of nature, a point which has recently taken hold among environmental ethicists thinking about technology in the anthropocene. ${ }^{22}$ Furthermore, Emerson is anticipating one of the common criticisms of contemporary ecotheology: that a certain ecological picture of the harmonious functioning of the parts of creation seems to condone wanton cruelty, especially between and among animals, because the virtue of ecological stability depends on the suffering of countless creatures in ways unfathomable to the limited comprehension of humans. Emerson's response is to say that when confronted with this suffering, we ought to take it as an occasion for a realization of ecstasy, that is, an indication of the overflowing of what we could possibly comprehend about nature. In this ecstatic moment, we check our world-making powers, discovering that there is more out there than what we can manage-and a theology that rationalizes this suffering through a theodicy limits our ability to see the perpetual inchoation of nature.

By the time he publishes "Nature" in 1844, the question of how one might come into harmony with this nature had only intensified. What was a young naturalist to do: leave the social world of the town in search of some closer relationship with the natural world, as many of Emerson's friends had done at both Fruitlands and Brook Farm? For the question of nature religion, we should wonder what kind of worship one might perform-what would it mean to take nature as sacred and therefore direct one's religious practice towards it. In this sense, Emerson's later "Nature" essay can be read as a direct confrontation with a nascent back-to-the-land movement among his peers, and for our purposes, it seems to lodge some of the claims that will eventually become most problematic for what I presented above as the nature religion tradition.

"Nature" begins with an unsurprising vision of "nature" as a resource that a young sojourner can use to escape the "knapsack of custom" that one finds in cities and human society, where he might find a "sanctity which shames our religions, and reality which discredits our heroes" (CW 3:99). Nature is a god-like judge of all things outside of human culture, carrying an authority to judge that culture and find it wanting (CW 3:100). In other words, nature is simultaneously a refuge outside of the human, and a resource that can correct the human. Some will enter this realm, leaving "villages and personalities behind," which he likens to a taking of religious vows (CW 3:101). This is the view that Emerson will label natura naturata, or nature passive; it is that created thing that stands apart from the human and which the human represents always in a slightly corrupted way, and by which the human can be measured, like a "differential thermometer" (CW 3:104). Poets and artists praise this nature; naturalists seek it out; it is the realm of unlimited beauty and unfathomable depths.

To the chagrin of the young naturalist-and perhaps the whole of the nature religion tradition-Emerson is not finally content with this view. He spends the rest of the essay trying to present an alternative, one that ultimately comes to trouble the very idea of a "nature". The turn in

22 As Rolston (2017) argues, as we confront the fact of the anthropocene, we ought not to do so with enthusiasm, lest we risk making our world entirely subservient to human flourishing. 
the essay occurs when Emerson comes to the realization that "we talk of deviations from natural life, as if artificial life were not also natural" (CW 3:106). Then, with a fell swoop, Emerson breaks down the distinction between nature and human society:

Nature who made the mason, made the house. We may easily hear too much of rural influences. The cool disengaged air of natural objects, makes them enviable to us chafed and irritable creatures with red faces, and we think we shall be as grand as they, if we camp out and eat roots; but let us be men instead of woodchucks, and the oak and the elm shall gladly serve us, though we sit in chairs of ivory on carpets of silk. (CW 3:106)

This is Emerson's sense of natura naturans, or efficient nature: the idea that nature is a whole that works in and through the various parts, the human especially, so much so that there ceases to be a distinction between nature and its opposite (here, the artificial, or the opulence of "chairs of ivory and carpets of silk"). One of the few to draw out the environmentalist implications of this move is Anderson (2008), who sees in it the sense that humans are involved in a complex relation of making and receiving with the various environments in which they are situated. By focusing on the importance of natura naturans, Anderson gives a reading of nature as not a passive recipient of human action, but as an agency that runs through the human, "doing, creating, making, moving." As Anderson puts it, "Nature is now not an objective environment but a creative environing" (Anderson 2008, pp. 154-55). This way of understanding the relationship between the human and the environment rejects the supposition that agency is an either/or: either the human is the active creative agent and nature the canvas, or nature is the active creative agent who merely works through the passive human. The former would lead to the Baconian view of nature as an instrument of human ends, one which White (1967) attributed to the dominance of a certain Christian understanding of the mastery of nature; the latter resembles a form of deep ecology that rejects entirely the constructive special agency of humans because of the intuition that nature is a kind of nondistinct unity (see Fox 1984).

These extremes are, of course, well-worn in conversations in environmental ethics, and it is now common to search out some middle or alternative way. Emerson's model is one such alternative. Anderson rightly focuses on the line quoted above, where Emerson reminds us to "be men instead of woodchucks." What this means is that we accept that we have a kind of agency that is part of nature's agency: "We are this aspect of nature, and we become 'not ourselves' if we slip into the state of mere witnesses of nature's judging perfection" (Anderson 2008, p. 155). There is a sense here that Emerson is trying to escape two problems, which I identified at the end of the previous section: first, not succumbing to the tendency to defer human power to the power of nature, while, second, not allowing the individual self to assume complete self-making power. ${ }^{23}$ To fall prey to the first problem is to insist that humans are merely another iteration of nature, and the highest good is that one return to a sense of the pristine created order of nature, camping out and eating roots. To do this would be to relinquish any claim to the world-making power that humans have both collectively and individually. ${ }^{24}$ But to go in the other direction, by supposing that humans are somehow distinct from and therefore entirely separate from nature, is to promote the worst kind of egoism for Emerson, an egoism that only drives the materialist and consumerist aspects of culture that make the world a commodity to be cataloged, processed, and exploited. For Emerson, we ought neither to deflate our agency to the agency of our environments, nor should our agency become entirely independent from the environments in which we live, work, and play. These environments are not complete-they are "systems of approximations," which are always changing in part due to human power, as well as reasons that humans only faintly

23 Greenham (2014, p. 90) rightfully puts it this way: "Emerson is of nature only insofar as he makes nature, and as nature's creator he does not share in its limitations but expresses through it the shaping power of his divinity."

24 You might say that it negates the possibility of ethical agency entirely. As Mooney $(2009$, p. 215) puts it: "If you reject the notion that 'I am the doer' in every sense, you reject the possibility of a philosophy of human action, and you lose all experiential purchase for reflection on reality as sustaining responsibility in an inexpugnable sense: namely, the possibility of responding, of our responding, in a way that is not arbitrary. Abstractly stated, man is a finite center of response." 
understand. We thus ought to see ourselves as "encamped in nature, not domesticated," wielding our world-making power in ways that are attentive to the very real connections that we have with the natural world (CW 3:110). It is both to honor the way that nature works through the human, while preserving the sense that humans have creative abilities to shape and reconfigure nature. For Anderson, to do this we need the notion of an "acquaintance" with nature: "One must engage nature directly to know by acquaintance; this is the enduring relevance of wilderness to human beings" (Anderson 2008, p. 156). The idea of acquaintance requires that the active self and the not-me of nature (in the language of Nature) work together through reciprocity, transaction, and integration, assuming "an attitude that is at once receptive to nature's language and open to human possibility" (Anderson 2008, pp. 158-59).

Whereas "The Method of Nature" focused on ecstasy, in "Nature" Emerson focuses on excess: both nature and the human have a kind of excess that prevents them from being set, from being a stable thing to which we can refer. Consequently, as for "men and women" as well as "silent trees," there is "always a referred existence, an absence, never a presence and satisfaction" (CW 3:112). Those who might wish to set themselves aright by bringing themselves in accord with nature discover that when they go looking for it, they will discover that they are "not near enough to his object" because "Nature is still elsewhere" (CW 3:111). But rather than despair of this, Emerson reminds us that this is precisely what ethics requires. As his is a perfectionism, it must always look out on a distant horizon. "The meeting of the sky and the earth," looked at from the smallest hill to the highest mountain, inspires action even as we are unable to get nearer to it. We are thrown back to the impermanence of our own ideas, of the work that must continually be performed without end, as the creatures we are. Thus, Emerson can say towards the end: "Nature is the incarnation of a thought, and turns to a thought again, as ice becomes water and gas. The world is mind precipitated, and the volatile essence is forever escaping again into the state of free thought. Hence the virtue and pungency of the influence on the mind, of natural objects, whether inorganic or organized" (CW 3:113). With the flowing impermanence of nature, Emerson affirms his moral perfectionism, which depends on a constantly extended horizon, and now has its mirror in how we experience "nature".

Let me end this section by turning to "Illusions," the final essay of The Conduct of Life from 1860. In many ways, "Illusion" presents the culmination of Emerson's idealism, directly dealing with the way that the human constitution-and the lack of awareness that we have of how our own powers determine how the world is present to us-amplifies the question of the environment. He sums this up with a rather poignant example: "At the State Fair, a friend of mine complained that all the varieties of fancy pears in our orchards seem to have been selected by somebody who had a whim for a particular kind of pear, and only cultivated such as had that perfume; they were all alike" (CW 6:9.9). The problem is that we do not know ourselves yet, and this makes it so that "Our conversation with Nature is not just what it seems" (CW 6:9.5). We cannot take our experiences of nature to be unmixed: "In admiring the sunset, we do not yet deduct the rounding, coördinating, pictorial powers of the eye" (CW 6:9.5). Emerson even reiterates that sentiment that he had given in Nature, that our joy is not the world's job, but it is something that we inscribe on the world, that colors it in certain ways. Or as he says, recalling his earlier essay, "Life is an ecstasy." (CW 6:9.6). As such, it isn't imperative that one strike out into the wilderness to find home, to leave the cities and towns that perpetuate the problems of human society; instead, the only "stays and foundations" that we have are "a strict and faithful dealing at home, and a severe barring out of all duplicity or illusion there" (CW 6:9.17).

Read this way, with an emphasis on home and the practical activities performed therein, "Illusions" is not a grand statement about the unreality of our environments, but a constant reminder not to be looking elsewhere for the source of our activities in the world. Ecstasy returns again as the position in which we check human hubris, relinquishing that theology that would make us more than what we actually are, but never reducing the human to just a power of the world for fear that this would annul agency altogether. 


\section{Conclusions}

As I hope is coming into focus, there is a way that Emerson's "nature" resembles more what we would now call "environment" because it seeks to avoid the totalizing of the not-human into a coherent and sound whole. Instead, it stresses the importance of the effects of human power in shaping nature-both our idea of nature, as well as the actual physical reality of nature-while stressing that the human is always intimately made by the environments in which we live. This is simultaneously a call to action and a call to humble oneself, to do the work that the human has the power to perform, while not supposing that the human has a special relationship for the benefit of nature. But more than anything, Emerson's confusion for the reality or illusion of nature is not unintended-it is part of the very ethos of ecstasy that he is hoping to inspire. When the nature religion tradition seeks to relinquish the tension between the dual ways that the human can relate to the surrounding environments, it domesticates the relationship and loses aspects of what Emerson believes is powerful about it: that our experience in the world isn't systematically coherent, but involves always a kind of doubleness. ${ }^{25}$

Furthermore, too often ethics stops before we get to practice-constructing a conceptual ideal but not saying how this might function within a set of ordinary social practices, the practices in which we are made and remade into the kinds of beings that we are and want to be. For Emerson, one of his essential question is: how ought religious institutions, which often coordinate the practices of a community, be reformed to better express higher ethical ideals. At certain moments, he goes so far as to say that "church" is just another word for "education" (EL 3:287). The fullest expression of this idea comes in The Conduct of Life, which seeks to describe in abstract ethical terms how the ordinary activities of people should be oriented towards their ethical development. Here, Emerson doesn't specify exactly which practices people ought to take up, but rather, he gives the general rubric under which we ought to think about those practices if the goal is to make religious worship more carefully attuned to pressing ethical demands.

What, then, can we say about an Emersonian Nature Religion? For many decades Emerson had been arguing that science and religion were more closely aligned than most of his contemporaries had thought. In fact, he rejected the idea that they were merely compatible for the idea that they were coming upon the same territory when properly understood. This meant rejecting both the idea that religion is concerned with the supernatural (or, that which is above scientific investigation) and the idea that science has no bearing on human moral becoming (in other words, he does not keep fact and value distinct). The goal, rather, is to allow scientific advances to have moral consequences. As he writes: "The religion which is to guide and fulfil the present and coming ages, whatever else it be, must be intellectual. The scientific mind must have a faith which is science" (CW 6:6.51). He then predicted what he thought this might be like: "There will be a new church founded on moral science, at first cold and naked, a babe in a manger again, the algebra and mathematics of ethical law, the church of men to come, without shawms, or psaltery, or sackbut; but it will have heaven and earth for its beams and rafters; science for symbol and illustration; it will fast enough gather beauty, music, picture, poetry" (CW 6:6.52). There are two important pieces to note. First we see Emerson's long insistence that religious institutions be primarily focused on the moral lives of their members by being willing to let go of what Emerson saw as antiquated ecclesiastical rituals-this is his intentionally arcane reference to shawms, psaltery, and sackbut. These will be replaced by a church that is fully situated in and of the world, with "heaven and earth for its beams and rafters," without reference to any other. It will take on science as "symbol and illustration," meaning that its core content is represented by the actual investigation of our world in conjunction with our moral reflection on it (here, moral science and natural science are brought together). This church includes the production of and reflection upon representational material ("beauty, music, picture, poetry") all of which express human ideals. This is,

25 One of the best expositions of this doubleness and its importance for ethical considerations of the self, see (Smith 2009). 
of course, part of a continual practice in which representations must be environmental. In Cavell's words, it is the community in search of achieving the ordinary.

But this church doesn't require an escape into untouched nature. ${ }^{26}$ It is a church of the community where it is located, for the people of that community, not, we might say, for woodchucks. It would seek to instill a sense of receptivity and piety in people, a meditation on the ecstasy of the environment that checks human hubris. But one can imagine that its "science" is not that of just the naturalist, but as much that of the investigating toxins surrounding the garbage dump, or the antibiotic resistant bacteria. Its goal is to shape the kinds of agents who can marry this knowing to doing, since as Emerson tells us, this is what it means to be truly learned (CW 1:136).

Conflicts of Interest: The author declares no conflict of interest.

\section{References}

Albanese, Catherine L. 1990. Nature Religion in America: From the Algonkian Indians to the New Age. Chicago: University of Chicago Press.

Albanese, Catherine L. 2002. Reconsidering Nature Religion. Harrisburg: Trinity Press International.

Anderson, Douglas R. 2008. Emerson's Natures: Origins of and Possibilities for American Environmental Thought. In New Morning: Emerson in the Twenty-first Century. Edited by Authur S. Lothstein and Michael Brodrick. Albany: State University of New York Press, pp. 151-60.

Berry, Evan. 2011. Nature Religion and the Problem of Authenticity. In Inherited Land: The Changing Grounds of Religion and Ecology. Edited by Kevin J. O'Brien, Richard Bohannon and Whitney Bauman. Eugene: Pickwick Publications.

Berry, Wendell. 2000. Life is a Miracle: An Essay against Modern Superstition. Washington: Counterpoint.

Brownson, Orestes A. 1991. Mr. Emerson's Address. In Boston Quarterly Review. October 1, Reprinted in Orestes A. Brownson Selected Writings; Edited by Patrick W. Carey. Mahwah: Paulist Press. First Published 1838.

Buell, Lawrence. 1995. The Environmental Imagination: Thoreau, Nature Writing, and the Formation of American Culture. Cambridge: The Belknap Press of Harvard University Press.

Buell, Lawrence. 2003. Emerson. Cambridge: Belknap Press of Harvard University Press.

Buell, Lawrence. 2005. The Future of Environmental Criticism: Environmental Crisis and Literary Imagination. Malden: Blackwell Publishing.

Bush, Stephen. 2014. Visions of Religion: Experience, Meaning, Power. Oxford: Oxford University Press.

Cavell, Stanley. 2002. Must We Mean What We Say? A Book of Essays, updated ed. Cambridge: Cambridge University Press.

Corrington, Robert S. 2002. My Passage from Panentheism to Pantheism. American Journal of Theology \& Philosophy 23: $129-53$.

Dacy, Barbara Jane. 2005. Nature Religion. In The Encyclopedia of Religion and Nature. Edited by Bron R. Taylor and Jeffrey Kaplan. London: Continuum.

Davies, Jeremy. 2016. The Birth of the Anthropocene. Oakland: University of California Press.

Emerson, Ralph Waldo. 1960-1982. The Journals and Miscellaneous Notebooks of Ralph Waldo Emerson. 16 vols. Edited by William H. Gilman, Alfred R. Ferguson, George P. Clark and Merrell R. Davis. Cambridge: Harvard University Press.

Emerson, Ralph Waldo. 1961-1972. The Early Lectures of Ralph Waldo Emerson. 3 vols. Edited by Stephen E. Whicher, Robert E. Spiller and Wallace E. Williams. Cambridge: Harvard University Press.

Emerson, Ralph Waldo. 1971-2013. The Collected Works of Ralph Waldo Emerson. 10 vols. Edited by Robert E. Spiller, Ronald A. Bosco, Alfred R. Ferguson, Joseph Slate and Jean Ferguson Carr. Cambridge: Harvard University Press.

26 As Mark Cladis has pointed out to me many times in our conversations, there is a better understanding of "wilderness," drawn from a "radical" Romantic tradition, that actually requires this kind of church because it doesn't see the wild as something distant from us, but as part of our everyday experience of who we are and the communities in which we live. 
Emerson, Ralph Waldo. 1989-1992. The Complete Sermons of Ralph Waldo Emerson. 4 vols. Edited by Albert J. Von Frank. Columbia: University of Missouri Press.

Feldman, Mark D., and Hsuan L. Hsu. 2007. Introduction: Race, Environment, and Representation. Discourse 29: 199-214.

Fox, Warwick. 1984. Deep Ecology: A New Philosophy of our Time? The Ecologist 14: 194-200.

Friedman, Randy L. 2009. Review essay on Listening on All Sides: Toward an Emersonian Ethics of Reading by Richard Deming. Transactions of the Charles S. Peirce Society 45: 114-20.

Friesner, Nicholas Aaron. 2017. Emerson's Transcendentalism of Common Life. Soundings: An Interdisciplinary Journal 100: 143-68. [CrossRef]

Gatta, John. 2004. Making Nature Sacred: Literature, Religion, and Environment in America from the Puritans to the Present. Oxford: Oxford University Press.

Gould, Rebecca Kneale. 2005. “Emerson, Ralph Waldo (1803-1882)”, “Thoreau, Henry David (1817-1862)”, and "Transcendentalism". In The Encyclopedia of Religion and Nature. 2 vols. Edited by Bron R. Taylor and Jeffrey Kaplan. London: Continuum.

Gottlieb, Roger S. 2006. Religion and Ecology-What Is the Connection and Why Does it Matter? In The Oxford Handbook of Religion and Ecology. Edited by Roger S. Gottlieb. Oxford: Oxford University Press, pp. 3-21.

Greenham, David. 2012. Emerson's Transatlantic Romanticism. New York: Palgrave Macmillan.

Greenham, David. 2014. Nature. In Ralph Waldo Emerson in Context. Edited by Wesley T. Mott. New York: Cambridge University Press, pp. 84-91.

Haraway, Donna. 2016. Staying with the Trouble: Making Kin in the Chthulucene. Durham: Duke University Press.

Hodder, Alan D. 2011. The Gospel According to this Moment: Thoreau, Wildness, and American Nature Religion. Religion and the Arts 15: 460-85. [CrossRef]

Lundin, Roger. 2005. From Nature to Experience: The American Search for Cultural Authority. Lanham: Rowman \& Littlefield Publishers.

Mooney, Edward F. 2009. Lost Intimacy in American Thought: Recovering Personal Philosophy from Thoreau to Cavell. New York: Continuum.

Nixon, Rob. 2011. Slow Violence and the Environmentalism of the Poor. Cambridge: Harvard University Press.

Packer, Barbara. 2007. Signing Off: Religious Indifference in America. In There Before Us: Religion, Literature, and Culture from Emerson to Wendell Berry. Edited by Roger Lundin. Grand Rapids: William B. Eerdman's Publishing, pp. 1-22.

Park, Lisa Sun-Hee, and David Naguib Pellow. 2011. The Slums of Aspen: Immigrants vs. The Environment in America's Eden. New York: New York University Press.

Pellow, David Naguib. 2002. Garbage Wars: The Struggle for Environmental Justice in Chicago. Cambridge: MIT Press.

Proudfoot, Wayne. 1987. Religious Experience. Berkeley: University of California Press.

Roberts, Tyler. 2013. Encountering Religion: Responsibility and Criticism after Secularism. New York: Columbia University Press.

Rolston, Holmes. 2017. The Anthropocene: Beyond the Natural? In The Oxford Handbook of Environmental Ethics. Edited by Stephen M. Gardiner and Allen Thompson. Oxford: Oxford University Press, pp. 62-73.

Smith, David L. 2009. "Who Shall Define to Me an Individual?" Emerson on Self, World, and God. American Journal of Theology \& Philosophy 30: 191-211.

Taves, Ann. 2009. Religious Experience Reconsidered: A Building-Block Approach to the Study of Religion and Other Special Things. Princeton: Princeton University Press.

Taylor, Bron R., and Gavin Van Horn. 2006. Nature Religion and Environmentalism in North America. In Faith in America: Changes, Challenges, New Directions. Edited by Charles H. Lippy. Westport: Praeger Publishers, vol. 3, pp. 165-90.

Van Anglen, Kevin. 1998. Reading Transcendentalist Texts Religiously: Emerson, Thoreau, and the Myth of Secularization. In Seeing into the Life of Things: Essays on Literature and Religious Experience. Edited by John L. Mahoney. New York: Fordham University Press, pp. 152-70.

White, Lynn, Jr. 1967. The Historical Roots of our Ecologic Crisis. Science 155: 1203-7. [CrossRef] [PubMed] 
Whyte, Kyle, and Chris Cuomo. 2017. Ethics of Caring in Environmental Ethics: Indigenous and Feminist Philosophies. In The Oxford Handbook of Environmental Ethics. Edited by Stephen M. Gardiner and Allen Thompson. Oxford: Oxford University Press, pp. 234-47.

Wordsworth, Dorothy. 2002. The Grasmere and Alfoxden Journals. Edited by Pamela Woof. Oxford: Oxford University Press. 